\title{
MENINGKATKAN AKTIVITAS DAN HASIL BELAJAR SISWA MELALUI MODEL PEMBELAJARAN KOOPERATIF TIPE JIGSAW BERBASIS ALGEBRATOR
}

\author{
Eline Yanty Putri Nasution*1, Farida Hanum Lubis ${ }^{2}$ \\ ${ }^{1}$ Institut Agama Islam Negeri (IAIN) Kerinci, Sungai Penuh, Jambi \\ ${ }^{2}$ SMP Negeri 1 Padangsidimpuan, Padangsidimpuan, Sumatera Utara \\ "e-mail: elineyantyputrinasution@iainkerinci.ac.id
}

\begin{abstract}
Abstrak. Penelitian ini merupakan penelitian tindakan kelas dengan 3 siklus sebagai kolaborasi penelitian antara dosen pendidikan matematika dengan guru matematika. Tujuan penelitian ini adalah menelaah model pembelajaran kooperatif tipe jigsaw berbasis Algebrator untuk meningkatkan aktivitas dan hasil belajar siswa dalam pembelajaran matematika. Pelenitian ini dilaksanakan pada salah satu sekolah menengah pertama dimana 215 orang siswa kelas delapan sebagai populasi, dan 21 orang siswa sebagai sampel penelitian. Penelitian ini menggunakan 8 buah instrumen baik tes maupun non-tes yang terlebih dahulu diuji coba validitasnya, yaitu: tes hasil belajar siswa I dengan nilai reliabilitas 0,80 (tinggi), tes hasil belajar siswa II dengan nilai reliabilitas 0,76 (tinggi), tes hasil belajar siswa III dengan nilai reliabilitas 0,81 (tinggi), skala aktivitas belajar siswa I dengan nilai reliabilitas 0,844 (sangat tinggi), skala aktivitas belajar siswa II dengan nilai reliabilitas 0,784 (tinggi), skala aktivitas belajar siswa III dengan nilai reliabilitas 0,878 (sangat tinggi), lembar observasi dan wawancara. Berdasarkan hasil analisis data, temuan dalam penelitian ini adalah: (1) rata-rata hasil belajar siswa pada siklus pertama adalah 65,62 (2) rata-rata hasil belajar siswa pada siklus kedua adalah 71,53 (3) rata-rata hasil belajar siswa pada siklus ketiga adalah 76 (4) rata-rata aktivitas belajar siswa pada siklus pertama adalah 41,29\% (5) rata-rata aktivitas belajar siswa pada siklus kedua adalah $50,71 \%$ (6) rata-rata aktivitas belajar siswa pada siklus ketiga adalah $65,24 \%$ (7) lembar observasi dan wawancara menunjukkan bahwa siswa merasa senang dan tertarik terhadap pembelajaran matematika dengan menggunakan model pembelajaran kooperatif tipe jigsaw berbasis Algebrator. Kesimpulan dari penelitian ini adalah model pembelajaran kooperatif tipe jigsaw berbasis Algebrator dapat meningkatkan aktivitas dan hasil belajar siswa dalam pembelajaran matematika.
\end{abstract}

Kata kunci: Jigsaw, Algebrator, Penelitian Tindakan Kelas, Aktivitas Belajar dan Hasil Belajar

\begin{abstract}
This study was classroom action research with 3 cycles as the research collaboration between mathematics education lecturer and mathematics teacher. The purpose of this study was investigated cooperative learning model type jigsaw based on Algebrator to improve student's activity and learning outcomes in mathematics learning. This study was implemented in one of the junior high school which 215 students of eighth grade as the population and 21 students as research sample. This study used 8 instruments not only test but also non-test that checked the validity first, that are: students' learning outcomes test I with reability score at 0.80 (high), students' learning outcomes test II with reability score at 0.76 (high), students' learning outcomes test III with reability score at 0.81 (high), students' learning activity scale I with reability score at 0.844 (very high), students' learning activity scale II with reability score at 0.784 (high), students' learning activity scale III with reability score at 0.878 (very high), observation sheet and interview. Based on the analysis of the data result, the finding of this study are: (1) the average of students' learning outcomes at the first cycle is 65.62 , (2) the average of students' learning outcomes at the second cycle is 71.53 , (3) the average of students' learning outcomes at the third cycle is 76 (4) the average of students' learning activity at the first cycle is $41.29 \%$, (5) the average of students' learning activity at the second cycle is $50.71 \%$, (6) the average of students' learning activity at the third cycle is $65.24 \%$ (7) observation and interview result indicate that students enjoyed and interested in mathematics learning using cooperative learning model type jigsaw based on Algebrator. The conclution is cooperative learning model type jigsaw based on Algebrator can improve students' activity and learning outcomes in mathematics learning.
\end{abstract}

Keywords: Jigsaw, Algebrator, Classroom Action Research, Learning Activity and Learning Outcomes 


\section{Pendahuluan}

Pembelajaran merupakan proses mengarahkan peserta didik untuk melakukan berbagai aktivitas belajar dalam rangka mencapai tujuan pembelajaran. Pencapaian tujuan pembelajaran yang dilakukan melalui berbagai aktivitas belajar siswa pada akhirnya bertujuan untuk memperoleh hasil belajar yang maksimal. Begitu juga dalam pembelajaran matematika. berbagai aktivitas belajar yang dilakukan oleh siswa diharapkan mampu mencapai hasil belajar matematika yang baik.

Sementara itu, dunia pendidikan matematika masih dihadapkan pada masalah rendahnya hasil belajar siswa. Hal ini juga mengindikasikan rendahnya aktivitas belajar siswa selama proses belajar mengajar matematika sedang berlangsung. Hasil belajar adalah kemampuan yang diperoleh siswa setelah melalui aktivitas belajar. Aktivitas belajar dan hasil belajar adalah dua hal yang tidak dapat dipisahkan (Nasution, 2016). Untuk itu, segala faktor yang mempengaruhi hasil belajar harus dioptimalkan untuk mencapai hasil belajar yang baik terutama proses belajar mengajar. Pada umumnya di sekolah-sekolah sering dijumpai siswasiswa yang tidak tertarik belajar matematika. Bagi siswa, pelajaran matematika sangat sulit, membingungkan dan susah dipahami sehingga menyebabkan hasil belajar matematika siswa rendah (Nasution, 2016) padahal matematika merupakan salah satu mata pelajaran yang penting untuk dipelajari.

Berdasarkan pengalaman penulis selama 29 tahun sebagai guru Matematika, pelajaran Matematika kurang diminati oleh sebahagian peserta didik. Data rata-rata hasil belajar siswa selama 3 tahun terakhir berada pada nilai 50, 51 dan 55. Hal ini mengindikasikan rendahnya aktivitas siswa. Rendahnya aktivitas siswa dalam belajar Matematika telah lama menjadi bahan pikiran yang mengganggu penulis. Siswa menunjukkan sikap yang kurang bergairah, kurang siap mengikuti pelajaran sehingga suasana kelas menjadi pasif. Umumnya siswa hanya mendengar penjelasan yang diberikan oleh guru pada saat pembelajaran sedang berlangsung. Siswa cenderung tidak berani bertanya dan tidak terbiasa mengajukan gagasan yang bermanfaat. Sikap ini muncul karena perasaan siswa yang takut salah dan takut ditertawakan oleh siswa lainnya. Hal ini disebabkan karena siswa belum menguasai pelajaran sepenuhnya sementara keberanian bertanya merupakan salah satu aktivitas belajar yang penting dalam pembelajaran matematika. Penulis menduga model pembelajaran yang digunakan selama ini belum efektif dimana penulis menggunakan metode ceramah lalu dilanjutkan dengan tanya jawab dan latihan. Penulis tidak memperhatikan bahwa kemampuan setiap siswa dalam menyerap informasi tidak sama sehingga mengakibatkan rata-rata hasil belajar siswa yang masih di bawah Kriteria Ketuntasan Minimal (KKM).

Untuk mengatasi permasalahan ini, guru matematika dituntut untuk memiliki kompetensi dalam menerapkan model pembelajaran yang aktif, efektif, kreatif dan inovatif yang dapat menimbulkan suasana pembelajaran yang nyaman dan menyenangkan sehingga mampu memicu aktivitas belajar siswa yang pada akhirnya mampu meningkatkan hasil belajar siswa. Dengan menggunakan model kooperatif hasil belajar siswa sangat diperhatikan agar mencapai ketuntasan yang diinginkan (Bagindo dan Yulia, 2019). Dalam hal ini guru menerapkan model pembelajaran kooperatif tipe jigsaw berbasis Algebrator yang diharapkan mampu meningkatkan baik aktivitas maupun hasil belajar siswa.

Model pembelajaran kooperatif membuat siswa termotivasi dan aktif untuk saling membantu dan mempersiapkan diri dalam menguasai materi pelajaran yang diberikan (Dewi 
\& Yulia, 2018). Model pembelajaran kooperatif tipe jigsaw memberi kesempatan bagi siswa untuk belajar baik secara mandiri maupun berkelompok. Keunggulan model pembelajaran ini adalah optimalisasi partisipasi siswa. Metode klasikal hanya memungkinkan satu orang siswa untuk tampil dan mempresentasikan hasil belajarnya di depan kelas. Sedangkan model pembelajaran kooperatif tipe Jigsaw mampu memberi kesempatan kepada setiap siswa sedikitnya delapan kali lebih banyak untuk menunjukkan partisipasi mereka kepada orang lain (Suparman, 2007).

Adapun langkah-langkah model pembelajaran Jigsaw adalah (a) siswa dibagi dalam kelompok yang disebut kelompok asal dimana setiap kelompok berjumlah sebanyak materi/topik permasalahan yang akan dibahas, (b) bentuk kelompok ahli yang anggotanya terdiri atas perwakilan dari tiap kelompok asal, (c) tiap kelompok ahli membahas suatu topik tertentu dimana topik yang dibahas pada tiap kelompok ahli berbeda, (d) setelah selesai bekerja di kelompok ahli, setiap siswa kembali ke kelompok asal masing-masing, (e) pada kelompok asal, setiap siswa menyampaikan apa yang diperoleh dan dipelajarinya di kelompok ahli, (f) setelah selesai belajar di kelompok ahli dan kelompok asal, diadakan kuis dan ulangan individu, dan (g) guru memberikan penghargaan kepada kelompok berdasarkan kumulatif nilai individual tertinggi (Sari, 2016).

Teknologi Informasi dan Komunikasi (TIK) yang diterapkan pada model pembelajaran kooperatif tipe jigsaw ini terdiri atas dua aspek yaitu teknologi informasi dan teknologi komunikasi. Teknologi informasi adalah suatu teknologi yang digunakan untuk mengolah data, termasuk memproses, mendapatkan, menyusun, menyimpan, manipulasi data dan berbagai cara untuk menghasilkan informasi yang berkualitas, yaitu informasi yang relevan, akurat dan tepat waktu (Menarianti \& Wibisono, 2013). Masih dari sumber yang sama, teknologi komunikasi mempunyai pengertian segala hal yang berkaitan dengan penggunaan alat bantu untuk memproses dan mentransfer data dari perangkat yang satu ke perangkat yang lain. Jadi teknologi informasi dan teknologi komunikasi merupakan media atau alat yang mempunyai fungsi menyampaikan pesan dalam proses pembelajaran. Hal ini sesuai dengan pernyataan Dirjen Manajemen Pendidikan Dasar dan Menengah yaitu penggunaan media pembelajaran berbasis TIK memungkinkan peserta didik dapat belajar secara runtut, sistematis, interaktif dan inovatif sehingga diharapkan semua kompetensi dapat dicapai secara utuh dan terpadu (Dirjen, 2010).

Pembelajaran adalah sebuah proses komunikasi antara siswa, guru dan bahan ajar. Komunikasi tidak akan berjalan tanpa bantuan sarana penyampai pesan atau media. Bentukbentuk stimulus bisa dipergunakan sebagai media di antaranya adalah hubungan atau interaksi manusia, realita, gambar bergerak atau gambar tidak bergerak, tulisan dan suara yang direkam baik menggunakan media komputer maupun media elektronik lainnya. Sebagai media pembelajaran, komputer tidak hanya berfungsi sebagai pembawa nuansa baru, tetapi juga berperan dalam mengembangkan bakat, minat, dan kemampuan siswa dalam pelajaran matematika (Nasution, 2017). Oleh sebab itu, adanya TIK dalam proses belajar mengajar diyakini mampu meningkatkan aktivitas belajar siswa.

Penerapan TIK dalam pembelajaran matematika dapat berupa penggunaan berbagai Software matematika yang relevan dengan materi yang diajarkan. Terdapat bayak Software 
yang berkaitan dengan pembelajaran matematika, dalam hal ini peneliti menggunakan Software Algebrator yang dianggap paling relevan pada materi yang dibahas pada penelitian ini, yaitu Sistem Persamaan Linear Dua Variabel (SPLDV). Algebrator adalah salah satu Software aljabar yang mampu menyelesaikan persoalan aljabar dan masalah geometri dasar dengan cara yang mudah, yaitu cukup dengan mengetik soal menggunakan bantuan beberapa toolbar yang ada, maka Algebrator akan membantu menyelesaikan persoalan tersebut disertai dengan penyajian langkah-langkah penyelesaian yang mudah dipahami (Nasution, 2018).

Berdasarkan hal yang telah dipaparkan sebelumnya, model pembelajaran kooperatif tipe jigsaw berbasis Algebrator diharapkan mampu meningkatkan baik aktivitas maupun hasil belajar siswa. Adapun aktivitas belajar siswa yang dimaksud dalam hal ini adalah a) aktivitas visual, yaitu: membaca, memperhatikan gambar demonstrasi, merumuskan; b) aktivitas bertanya, yaitu memberi saran, mengeluarkan pendapat, mengadakan wawancara, diskusi, interupsi; c) aktivitas mendengar, yaitu: mendengar uraian, percakapan, diskusi, musik, pidato; d) aktivitas menulis, yaitu menulis cerita, karangan, laporan, angket, dan menyalin pelajaran; e) aktivitas menggambar, yaitu: menggambarkan grafik, peta, diagram; f) aktivitas kerja, yaitu: melakukan percobaan, membuat konstruksi model, merevarasi, bermain, berkebun, beternak; g) aktivitas mental, yaitu: menganggap, mengingat, memecahkan soal, menganalisa, melihat hubungan, mengambil keputusan; dan h). aktivitas emosional, yaitu menaruh minat, merasa bosan, gembira, berani tenang, gugup (Sardiman, 2009). Berdasarkan pendapat di atas maka aktivitas belajar yang penulis amati bersesuaian dengan penerapan model pembelajaran kooperatif tipe jigsaw berbasis Algebrator adalah aktivitas siswa mengajukan pertanyaan, aktivitas siswa memberikan jawaban, aktivitas siswa menanggapi atau memberi saran, aktivitas siswa menulis dan aktivitas keseriusan siswa.

\section{Metode Penelitian}

Jenis penelitian ini adalah Penelitian Tindakan Kelas (Classroom Action Research) dengan tujuan untuk meningkatkan aktivitas dan hasil belajar siswa. Penelitian ini dilaksanakan di SMP Negeri 1 Padangsidimpuan, Sumatera Utara dimana salah satu penulis merupakan guru matematika di sekolah tersebut. Populasi penelitian ini adalah seluruh siswa kelas VIII sebanyak 215 orang dan 21 orang siswa kelas VIII-9 sebagai sampel penelitian.

Penelitian ini menggunakan instrumen tes dan non-tes, yaitu tes hasil belajar siswa, skala aktivitas belajar siswa, lembar observasi dan wawancara yang dianalisis secara kualitatif dan kuantitatif yang bertujuan untuk mengetahui aktivitas dan hasil belajar siswa pada materi SPLDV selama 12 kali pertemuan. Penggunaan instrumen-instrumen tersebut dipilih berdasarkan Triangulasi Data yang bertujuan untuk memastikan keabsahan data (Nasution, 2019). Instrumen tes hasil belajar siswa disusun berdasarkan kisi-kisi yang disesuaikan dengan indikator hasil belajar serta Taksonomi Bloom pada ranah kognitif siswa sekolah menengah pertama yaitu c1, c2 dan c3. Instrumen tes ini terlebih dahulu dianalisis validitas, reabilitas, tingkat kesukaran soal dan daya pembeda dengan menggunakan aplikasi Anates.

Berdasarkan hasil analisis uji coba instrumen Tes Hasil Belajar I dengan menggunakan Anates diperoleh bahwa seluruh butir soal memiliki validitas yang tinggi dimana 3 butir soal sangat signifikan dan selebihnya signifikan. Untuk daya pembeda, terdapat 1 butir soal memiliki daya pembeda sangat baik dan selebihnya memiliki daya pembeda yang baik. Untuk 
tingkat kesukaran soal, terdapat 1 butir soal mudah, 1 butir soal sukar dan selebihnya sedang. Secara keseluruhan, Tes Hasil Belajar I memiliki reliabititas tinggi.

Berdasarkan hasil analisis uji coba instrumen Tes Hasil Belajar II dengan menggunakan Anates diperoleh bahwa seluruh butir soal memiliki validitas yang tinggi dimana 2 butir soal sangat signifikan dan selebihnya signifikan. Untuk daya pembeda, terdapat 2 butir soal memiliki daya pembeda sangat baik dan selebihnya memiliki daya pembeda yang baik. Untuk tingkat kesukaran soal, terdapat 1 butir soal mudah, 1 butir soal sukar dan selebihnya sedang. Secara keseluruhan, Tes Hasil Belajar II memiliki reliabititas tinggi.

Berdasarkan hasil analisis uji coba instrumen Tes Hasil Belajar III dengan menggunakan Anates diperoleh bahwa seluruh butir soal memiliki validitas yang tinggi dimana 2 butir soal sangat signifikan dan selebihnya signifikan. Untuk daya pembeda, terdapat 2 butir soal memiliki daya pembeda sangat baik dan selebihnya memiliki daya pembeda yang baik. Untuk tingkat kesukaran soal, terdapat 1 butir soal mudah, 1 butir soal sukar dan selebihnya sedang. Secara keseluruhan, Tes Hasil Belajar II memiliki reliabititas tinggi.

Sementara itu, instrumen non-tes dianalisis validitas dan reliabilitasnya dengan menggunakan aplikasi SPSS. Berdasarkan hasil analisis uji coba instrumen Skala Aktivitas Belajar I dengan menggunakan SPSS diperoleh bahwa terdapat 2 buah pernyataan yang tidak valid sehingga kedua pernyataan tersebut tidak dipakai dalam instrumen. Oleh sebab itu, terdapat 22 buah pernyataan yang valid dengan reliabilitas sangat tinggi. Kemudian berdasarkan hasil analisis uji coba instrumen Skala Aktivitas Belajar II dengan menggunakan SPSS diperoleh bahwa seluruh pernyataan (22 buah) valid dengan reliabilitas tinggi. Hal yang sama juga terjadi pada instrumen Skala Aktivitas Belajar III, yaitu seluruh pernyataan (22 buah) valid tetapi dengan reliabilitas sangat tinggi.

Lembar observasi dan pedoman wawancara disusun berdasarkan indikator aktivitas belajar siswa yang kemudian dianalisis validitasnya oleh 5 orang ahli dalam Pendidikan Matematika, yaitu dua orang dosen Pendidikan Matematika dan 3 orang Guru Matematika. Berdasarkan hasil analisis para ahli tersebut, maka dihasilkan lembar observasi dan pedoman wawancara yang valid.

Seluruh data yang diperoleh dari instrumen penelitian selanjutnya dianalisis untuk melihat peningkatan baik aktivitas maupun hasil belajar siswa. Adapun kategori peningkatan aktivitas belajar siswa (Rosba, 2015) dipaparkan pada Tabel 1. berikut:

Tabel 1. Kategori peningkatan aktivitas belajar siswa

\begin{tabular}{ccc}
\hline No. & Interval (Dalam \%) & Kategori \\
\hline 1. & $81-100$ & Sangat Baik \\
2. & $61-80$ & Baik \\
3. & $41-60$ & Cukup \\
4. & $1-40$ & Kurang \\
\hline
\end{tabular}


Penelitian ini diawali dengan analisis permasalahan pada pra siklus kemudian memulai penelitian pada Siklus I. Pada pra siklus, peneliti menelaah permasalahan yang terjadi pada pembelajaran matematika. Pada Siklus I, peneliti melaksanakan pembelajaran matematika untuk mengatasi permasalahan tersebut. Terlebih dahulu dianalisis alternatif pemecahan masalah melalui rencana tindakan, kemudian melaksanakan tindakan, observasi, analisis data dan refleksi. Apabila berdasarkan hasil refleksi permasalahan belum terselesaikan, maka penelitian berlanjut ke Siklus II dan seterusnya dengan langkah yang sama. Berdasarkan langkah-langkah penelitian tersebut, maka penelitian ini terdiri atas 3 siklus.

Pada pelaksanaan Siklus I, dilakukan pembelajaran matematika pada materi SPLDV dengan menggunakan metode substitusi dan eliminasi masing-masing sebanyak dua kali pertemuan. Penulis sebagai guru dan peneliti dibantu oleh dua orang observer untuk mengamati dan mencatat aktivitas siswa yang muncul. Pada akhir siklus diberikan tes hasil belajar I, skala aktivitas belajar I serta wawancara. Berdasarkan hasil analisis instrumeninstrumen penelitian tersebut dilakukan refleksi terhadap pelaksanaan pembelajaran pada Siklus I. Hasil refleksi menunjukkan bahwa aktivitas belajar siswa masih belum memuaskan dan nilai rata-rata hasil belajar siswa masih berada di bawah KKM (75). Hal ini disebabkan karena pembagian kelompok ternyata belum heterogen, Pengelompokan siswa pada Siklus I ini tidak dilakukan berdasarkan nilai ujian tengah semester siswa, tetapi berdasarkan hasil pengamatan peneliti terhadap kemampuan siswa selama menjadi guru Matematika di kelas tersebut. Hal ini menyebabkan penelitian berlanjut ke Siklus II.

Siklus II dilaksanakan dengan melakukan tindakan yang dianggap kurang pada Siklus I. Tindakan tersebut adalah mengadakan penggantian teman sekelompok dan ketua kelompok. Hal ini dilakukan berdasarkan hakikat model pembelajaran kooperatif dimana pembentukan kelompok harus heterogen. Heterogenitas kelompok mencakup jenis kelamin, agama, suku, ras dan kemampuan kognitif siswa (Sari, 2016). Kurangnya tindakan pada Siklus I disebabkan oleh adanya pengelompokan yang kurang heterogen. Heterogenitas kelompok pada Siklus I dianggap kurang sebab berdasarkan hasil observasi, masih terlihat beberapa orang anggota kelompok yang tidak terlibat dalam diskusi kelompok.

Materi yang dipelajari pada Siklus II ini adalah SPLDV dengan menggunakan metode reduksi dan grafik masing-masing sebanyak dua kali pertemuan. Penulis sebagai guru dan peneliti dibantu oleh dua orang observer untuk mengamati dan mencatat aktivitas siswa yang muncul. Pada akhir siklus diberikan tes hasil belajar II, skala aktivitas belajar II serta wawancara. Berdasarkan hasil analisis instrumen-instrumen penelitian tersebut dilakukan refleksi terhadap pelaksanaan pembelajaran pada Siklus II. Hasil refleksi menunjukkan bahwa aktivitas belajar dan hasil belajar siswa sudah meningkat namun belum signifikan dan masih berada di bawah KKM (75). Hal ini disebabkan karena pada Siklus II, model pembelajaran kooperatif tipe Jigsaw belum sepenuhnya mampu mengatasi gaya belajar siswa yang bervariasi khususnya pada gaya belajar Audio Visual. Oleh sebab itu diperlukan suatu tindakan untuk mengatasi hal tersebut. Hal ini menyebabkan penelitian berlanjut ke Siklus III.

Siklus III dilaksanakan dengan melakukan tindakan yang dianggap kurang pada Siklus II. Tindakan tersebut adalah menggunakan Software matematika, yaitu Software Algebrator selama proses belajar mengajar pada materi membuat dan menyelesaikan model matematika dari masalah sehari-hari yang berkaitan dengan SPLDV masing-masing sebanyak dua kali pertemuan. Tindakan tersebut dilakukan berdasarkan pernyataan Dirjen Manajemen 
Pendidikan Dasar dan Menengah tentang penggunaan media berbasis TIK dalam proses pembelajaran untuk meningkatkan hasil belajar siswa.

Adapun diagram alir tahapan atau langkah-langkah penelitian di setiap siklus pada penelitian tindakan kelas ini digambarkan sebagai berikut:

SIKLUS I

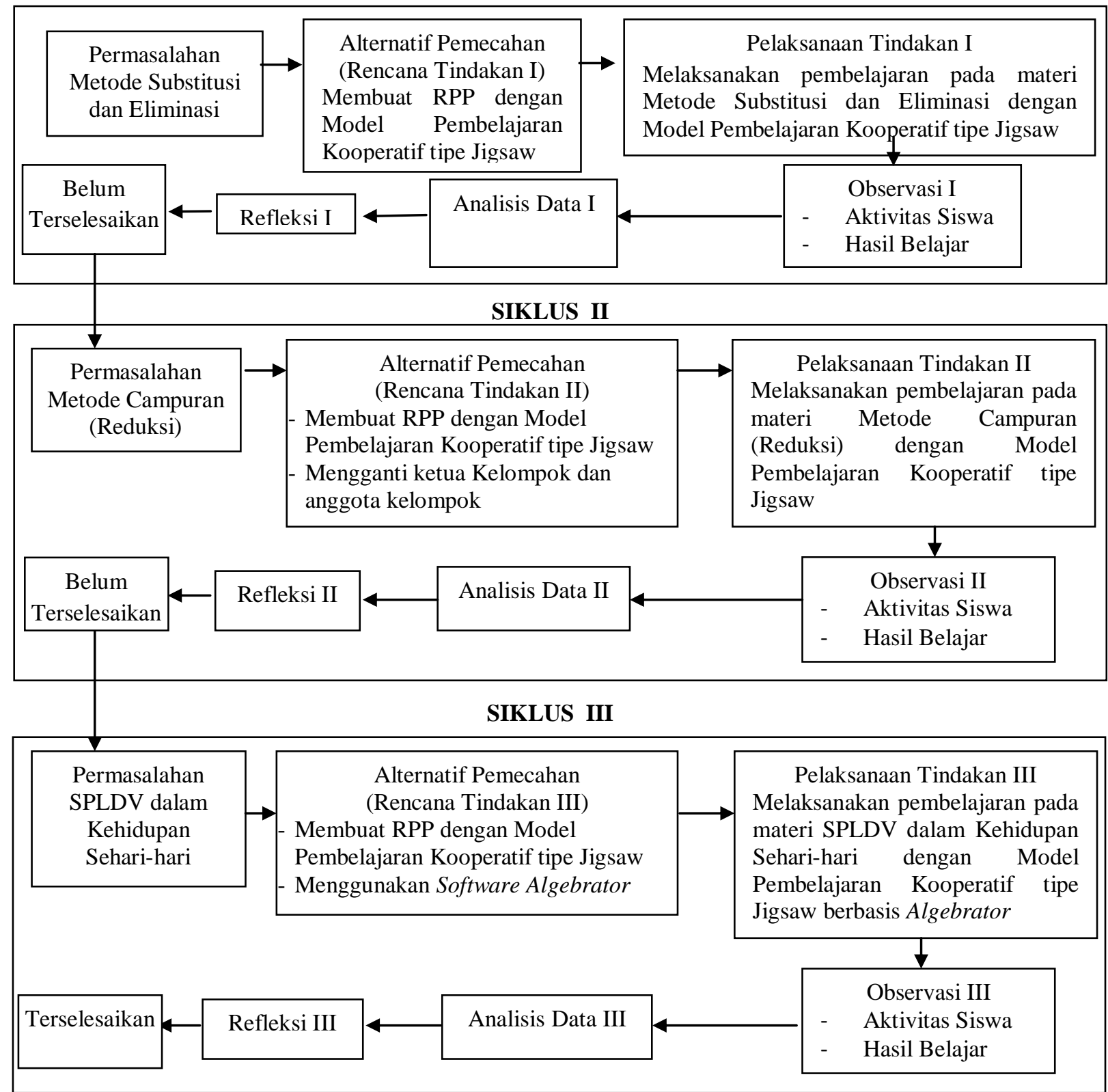

Gambar 1. Diagram Alir Tahapan Penelitian Setiap Siklus

Pemilihan Software Algebrator dilakukan karena Software tersebut dianggap paling relevan untuk materi SPLDV serta paling mudah digunakan oleh siswa tingkat SMP. Pembelajaran dilaksanakan di ruang laboratorium komputer dimana setiap perangkat komputer telah terinstall Software tersebut. Siswa baik di dalam kelompok asal maupun 
kelompok ahli menyelesaikan persoalan SPLDV dalam kehidupan sehari-hari berbantuan Software Algebrator. Penulis sebagai guru dan peneliti dibantu oleh dua orang observer untuk mengamati dan mencatat aktivitas siswa yang muncul. Pada akhir siklus diberikan tes hasil belajar III, skala aktivitas belajar III serta wawancara. Berdasarkan hasil analisis instrumeninstrumen penelitian tersebut dilakukan refleksi terhadap pelaksanaan pembelajaran pada Siklus III. Hasil refleksi menunjukkan bahwa aktivitas belajar dan hasil belajar siswa sudah meningkat secara signifikan dan sudah berada di atas KKM (75) sehingga penelitian berhenti di Siklus III.

\section{Hasil Penelitian dan Pembahasan}

Skala aktivitas belajar siswa pada setiap siklus dianalisis secara kualitatif dengan mendaftar seluruh aktivitas belajar siswa yang muncul pada saat proses pembelajaran sedang berlangsung. Selanjutnya menentukan persentase masing-masing kategori aktivitas belajar siswa yang kemudian menentukan persentase total aktivitas belajar siswa pada setiap siklus.

Hasil analisis skala aktivitas belajar siswa didukung oleh hasil analisis observasi dan wawancara secara kualitatif. Sementara itu berdasarkan hasil analisis tes hasil belajar pada setiap siklus diperoleh rata-rata hasil belajar siswa yang kemudian ditelaah apakah telah mencapai nilai Kriteria Ketuntasan Minimal (KKM) yaitu 75. Adapun rangkuman hasil penelitian ini dipaparkan pada tabel berikut:

Tabel 2. Rangkuman hasil penelitian

\begin{tabular}{|c|c|c|c|c|c|c|c|c|c|c|c|c|c|}
\hline \multirow{4}{*}{$\begin{array}{l}\text { Sik } \\
\text {-lus }\end{array}$} & \multicolumn{10}{|c|}{ Aktivitas } & \multirow{4}{*}{$\begin{array}{l}\text { Total } \\
\text { Akti } \\
\text { vitas }\end{array}$} & \multirow{4}{*}{$\%$} & \multirow{4}{*}{$\begin{array}{l}\text { Rata2 } \\
\text { Hasil } \\
\text { Be- } \\
\text { lajar }\end{array}$} \\
\hline & \multicolumn{2}{|c|}{ Bertanya } & \multicolumn{2}{|c|}{ Menjawab } & \multicolumn{2}{|c|}{ Menanggapi } & \multicolumn{2}{|c|}{ Menulis } & \multicolumn{2}{|c|}{ Keseriusan } & & & \\
\hline & $\mathrm{Jlh}$ & Jlh & $\mathrm{Jlh}$ & $\mathrm{Jlh}$ & Jlh & Jlh & $\mathrm{Jlh}$ & $\mathrm{Jlh}$ & $\mathrm{Jlh}$ & Jlh & & & \\
\hline & Siswa & Aktv & Siswa & Aktv & Siswa & Aktv & Siswa & Aktv & Siswa & Aktv & & & \\
\hline I & 8 & 20 & 12 & 27 & 8 & 18 & 21 & 50 & 21 & 50 & 165 & 41,29 & 65,62 \\
\hline II & 14 & 31 & 16 & 39 & 14 & 26 & 21 & 57 & 21 & 60 & 213 & 50,71 & 71,53 \\
\hline III & 17 & 42 & 18 & 49 & 20 & 46 & 21 & 67 & 21 & 70 & 273 & 65,24 & 76 \\
\hline
\end{tabular}

Pada Siklus I, terdapat 8 orang siswa yang mengajukan pertanyaan dengan jumlah aktivitas 20 dan persentase $23,81 \%$. Siswa yang memberikan jawaban sebanyak 12 orang dengan jumlah aktivitas 27 dan persentase 32,14\%. Siswa yang menanggapi atau memberi saran sebanyak 8 orang dengan jumlah aktivitas 18 dan persentase $21,43 \%$. Siswa yang menulis sebanyak 21 orang dengan jumlah aktivitas 50 dan persentase 59,52\%. Keseriusan siswa dalam mengikuti pembelajaran adalah sebanyak 21 orang siswa yang berperan aktif dalam kerja kelompok dengan jumlah aktivitas 50 dan dengan persentasi 59,52\%. Persentase aktivitas belajar siswa pada Siklus I secara keseluruhan adalah 41,29\% dengan kriteria cukup. Sementara itu nilai rata-rata hasil belajar siswa adalah 65,62 dan masih berada di bawah KKM. Siklus I ini dipengaruhi oleh efek dari langkah kelima pada model pembelajaran kooperatif tipe Jigsaw, yaitu setiap siswa pada kelompok asal menyampaikan apa yang diperoleh dan dipelajarinya di kelompok ahli sehingga terjadi peningkatan baik aktivitas maupun hasil belajar siswa.

Pada Siklus II, terdapat 14 orang siswa yang mengajukan pertanyaan dengan jumlah aktivitas 31 dan persentase $36,9 \%$ naik dari $23,81 \%$ pada Siklus I. Siswa yang memberikan 
jawaban sebanyak 16 orang dengan jumlah aktivitas 39 dan persentase 46,43\% naik dari $32,14 \%$ pada Siklus I. Siswa yang menanggapi atau memberi saran sebanyak 14 orang dengan jumlah aktivitas 26 dan persentase $30,95 \%$ naik dari $21,43 \%$ pada siklus I. Siswa yang menulis sebanyak 21 orang dengan jumlah aktivitas 57 dan persentase $67,86 \%$ naik dari $59,52 \%$ pada Siklus I. Keseriusan siswa dalam mengikuti pembelajaran adalah sebanyak 21 orang siswa yang berperan aktif dalam kerja kelompok dengan jumlah aktivitas 60 dan dengan persentasi $71,43 \%$ naik dari $59,52 \%$ pada Siklus I. Persentase aktivitas belajar siswa pada Siklus II secara keseluruhan adalah 50,71\% dengan kriteria cukup. Sementara itu nilai rata-rata hasil belajar siswa adalah 71,53 dan masih berada di bawah KKM. Siklus II ini dipengaruhi oleh efek dari langkah keenam pada model pembelajaran kooperatif tipe Jigsaw, yaitu adanya kuis dan ulangan individu sehingga terjadi peningkatan baik aktivitas maupun hasil belajar siswa.

Pada Siklus III, terdapat 17 orang siswa yang mengajukan pertanyaan dengan jumlah aktivitas 42 dan persentase naik dari 36,9\% menjadi 50,00\%. Siswa yang memberikan jawaban sebanyak 18 orang dengan jumlah aktivitas 49 dan persentase naik dari 46,43\% menjadi 58,33\%. Siswa yang menanggapi atau memberi saran sebanyak 20 orang dengan jumlah aktivitas 46 dan persentase naik dari 30,95\% menjadi 54,76\%. Siswa yang menulis sebanyak 21 orang dengan jumlah aktivitas 67 dan persentase 67,86\% menjadi 79,76\%. Keseriusan siswa dalam mengikuti pembelajaran adalah sebanyak 21 orang siswa yang berperan aktif dalam kerja kelompok dengan jumlah aktivitas 70 dan dengan persentasi $71,43 \%$ menjadi $83,33 \%$. Persentase aktivitas belajar siswa pada Siklus III secara keseluruhan adalah 65,24\% dengan kriteria baik. Sementara itu nilai rata-rata hasil belajar siswa adalah 76 dan telah berada di atas KKM dengan kriteria baik. Siklus III ini dipengaruhi oleh efek dari penggunaan Software Algebrator pada model pembelajaran kooperatif tipe Jigsaw sehingga terjadi peningkatan baik aktivitas maupun hasil belajar siswa.

Berdasarkan Tabel 2 di atas tampak bahwa di setiap siklus terdapat peningkatan aktivitas belajar siswa pada setiap kategori aktivitas maupun keseluruhan aktivitas belajar. Jumlah siswa yang melakukan aktivitas belajar juga meningkat pada setiap siklus. Meskipun pada beberapa kategori aktivitas belajar terdapat jumlah siswa yang sama dalam melakukan beberapa kategori aktivitas belajar, namun jumlah aktivitas belajar siswa yang terjadi semakin meningkat. Misalnya pada Siklus I, terdapat 21 siswa yang melakukan aktivitas menulis. Hal yang sama juga tampak pada Siklus II dan Siklus III. Namun pada Siklus I, 21 siswa tersebut melakukan aktivitas menulis sebanyak 50 aktivitas dan meningkat menjadi 57 aktivitas pada Siklus II serta meningkat menjadi 67 aktivitas pada Siklus III. Hal ini menunjukkan bahwa seluruh siswa kelas VIII-9 yang berjumlah 21 orang telah melakukan aktivitas menulis mulai dari Siklus I hingga ke Siklus III. Hal ini logis sebab aktivitas menulis tentu saja merupakan aktivitas yang pasti dilakukan oleh siswa pada pembelajaran matematika, hanya saja tingkat intensitas aktivitas menulis tersebut terus meningkat pada setiap siklus.

Berdasarkan Tabel 2 di atas juga tampak bahwa terdapat peningkatan rata-rata hasil belajar siswa pada setiap siklus, yaitu 65,62 pada Siklus I, 71,53 pada Siklus II dan 76 pada Siklus III. Penelitian berlanjut hingga ke Siklus III sebab peningkatan yang terjadi belum signifikan dan rata-rata hasil belajar siswa berada di atas KKM baru tercapai pada Siklus III. 
Hasil analisis observasi dan wawancara berbanding lurus terhadap hasil analisis skala aktivitas dan hasil belajar siswa sehingga aktivitas dan hasil belajar siswa dapat ditingkatkan melalui penerapan model pembelajaran kooperatif tipe Jigsaw berbasis Algebrator.

Penelitian tindakan kelas serupa oleh Nur Basuki pada tahun 2015 dalam meningkatkan aktivitas dan hasil belajar siswa dengan menggunakan model pembelajaran kooperatif tipe Jigsaw berhenti pada Siklus II dimana nilai rata-rata hasil belajar 72,50 dengan persentase aktivitas belajar sebesar 70,5\%. Penelitian tersebut berhenti di Siklus II sebab rata-rata hasil belajar siswa yaitu 72,50 telah berada di atas KKM (60). Apabila penelitian tersebut dilanjutkan ke Siklus III dengan menggunakan Software Algebrator seperti pada penelitian ini, maka dapat diyakini akan meningkatkan nilai rata-rata hasil belajar siswa. Selanjutnya, meskipun persentase aktivitas belajar pada penelitian terdahulu tersebut $(70,5 \%)$ terlihat lebih tinggi, namun tetap berada pada kategori yang sama dengan persentase aktivitas belajar pada penelitian ini $(65,24 \%)$ yaitu sama-sama berada pada kategori "Baik". Oleh sebab itu, pemilihan model pembelajaran kooperatif tipe Jigsaw berbasis Algebrator dalam meningkatkan aktivitas dan hasil belajar siswa pada pembelajaran matematika sudah tepat (Basuki, 2015).

\section{Kesimpulan}

Berdasarkan hasil penelitian sebagaimana yang dipaparkan sebelumnya dapat disimpulkan bahwa:

1. Terdapat peningkatan aktivitas belajar siswa pembelajaran Matematika melalui penerapan model pembelajaran kooperatif tipe Jigsaw berbasis Algebrator yaitu 41,29\% (cukup) pada Siklus I, meningkat menjadi 50,71\%(cukup) pada Siklus II kemudian meningkat menjadi $65,24 \%$ (baik) pada Siklus III.

2. Terdapat peningkatan hasil belajar siswa pada pembelajaran Matematika melalui penerapan model pembelajaran kooperatif tipe Jigsaw berbasis Algebrator dengan kategori "baik", dengan rata-rata hasil belajar siswa pada Siklus I adalah 65,62, pada Siklus II dengan nilai rata-rata 71,53 serta pada Siklus III dengan nilai rata-rata 76,00.

3. Siswa merasa senang dan tertarik terhadap pembelajaran matematika dengan menggunakan model pembelajaran kooperatif tipe jigsaw berbasis Algebrator.

\section{DAFTAR PUSTAKA}

Bagindo, R., \& Yulia, P. (2019). Efektivitas Model Pembelajaran Aptitude Treatment Interaction (ATI) dengan Team Assisted Individualization (TAI) terhadap Hasil Belajar Siswa. PYTHAGORAS: Jurnal Program Studi Pendidikan Matematika, 8(1).

Basuki, N. (2015). Peningkatan Aktivitas dan Hasil Belajar Siswa menggunakan Model Pembelajaran Kooperatif Tipe Jigsaw pada Mata Pelajaran Matematika Siswa Kelas VII SMPN 2 Bumiratu Nuban Tahun Pelajaran 2014/2015. AKSIOMA: Jurnal Program Studi Pendidikan Matematika, 4(1).

Dewi, E.K., \& Yulia, P. (2018). Efektivitas Penerapan Model Pembelajaran TAI dan PBI terhadap Hasil Belajar Matematika Siswa Kelas VIII SMPN 50 Batam. PYTHAGORAS: Jurnal Program Studi Pendidikan Matematika, 7(2). 
Dirjen Manajemen Pendidikan Dasar dan Menengah. (2010). Panduan Pengembangan Bahan Ajar Berbasis TIK. Jakarta: Kemendiknas.

Menarianti, Ika \& Wibisono, Arif. (2013). Teknologi Informasi dan Komunikasi. Semarang: IKIP PGRI Semarang.

Nasution, E. Y. P. (2016). Upaya Meningkatkan Hasil Belajar Siswa Dengan Menggunakan Teknik Pembelajaran Hypnoteaching. Logaritma: Jurnal Ilmu-ilmu Kependidikan dan Sains, 3(1), 78-95.

. (2017). Meningkatkan Kemampuan Spasial Siswa Melalui Pembelajaran Geometri Berbantuan Cabri 3D. Jurnal Matematika dan Pendidikan Matematika, 2(2), 179-194.

. (2018). Buku Panduan Praktikum Matematika. Laboratorium FTIK: Tadris Matematika IAIN Kerinci.

. (2019). Interaksi antara Peningkatan Kemampuan Berpikir Kreatif Siswa dengan Pendekatan Open-Ended dan Kemampuan Awal Matematis Siswa. Proximal: Jurnal Penelitian Matematika dan Pendidikan Matematika, 2(1).

Rosba, Eriani. (2015). Peningkatan Aktivitas dan Hasil Belajar Siswa menggunakan Pembelajaran Think Pair Share yang Disertai LKS pada Mata Pelajaran IPA-Biologi Kelas VII A SMP Taman Siswa Padang. Bioconcetta: Jurnal Penelitian Pendidikan Biologi, 1(2).

Sardiman, A.M. (2009). Interaksi dan Motivasi Belajar Mengajar. Jakarta: PT Raja Grafindo Persada.

Sari, L. N. I. (2016). Perangkat Pembelajaran berbasis Model Pembelajaran Kooperatif Tipe Jigsaw. Logaritma: Jurnal Ilmu-ilmu Pendidikan dan Sains, 4(02), 43-57.

Suparman, Atwi. (2007). Model-Model Pembelajaran Interaktif. Jakarta: STA LAN Press. 